Research Article

\title{
Increasing Growth Tiger Prawn (Penaeus monodon) Using Organic Diet of Sauropus androgynous
}

\author{
Awaludin ${ }^{1 *}$, Ira Maya Abdiani ${ }^{2}$, Ahmad $^{1}$, Rukisah ${ }^{1}$ \\ ${ }^{1}$ Department of Aquaculture, Universitas Borneo Tarakan, Tarakan 77123, Indonesia \\ ${ }^{2}$ Department of Fisheries Product Technology, Universitas Borneo Tarakan, Tarakan 77123, Indonesia
}

\section{Article history:}

Submission July 2020

Revised August 2020

Accepted September 2019

*Corresponding author:

E-mail: awaludin@borneo.ac.id

\begin{abstract}
Sauropus androgynous contain chemical compounds that can increase the growth of tiger prawn. This study aims to determine the growth of tiger prawns after giving $S$. androgynous leaves ethanol extract mixed in feed. The research method uses a completely randomized design (CRD) 4 treatments, three replications. Treatment with a dose of Treatment 1 (T1) Control without giving $S$. androgynous extract, Treatment 2 (T2) $5 \mathrm{gr} / \mathrm{kg}$ of feed, Treatment 3 (T3) $50 \mathrm{gr} / \mathrm{kg}$ of feed, Treatment 4 (T4) $100 \mathrm{gr} / \mathrm{kg}$ of feed. Proximate test results of $S$. androgynous extract crude protein content of $10.83 \%$, crude fiber $1.87 \%$, crude fat $0.85 \%$, ash content $1.94 \%$, dry weight $93.62 \%$, and extract material without nitrogen $78.13 \%$. Based on the results of the study, the weight growth and growth length statistically showed significantly different $(\mathrm{P}<0.05)$. The highest growth of tiger prawn at the end of the study was found in P4 by giving S. androgynous leaf extract with an average weight growth value $(70.18 \pm 9.57 \mathrm{~g})$. While the lowest weight growth was observed in T1 with an average weight growth value (32.62 $\pm 7.54 \mathrm{~g})$. The highest length growth was found in T4 with average length $(1.19 \pm 0.10 \mathrm{~cm})$, while the lowest length growth was seen in $\mathrm{T} 1$ with average length growth $(0.62 \pm 0.09 \mathrm{~cm})$.
\end{abstract}

Keywords: Diet, Growth, Penaeus monodon, Plant Extracts, Sauropus androgynous

\section{Introduction}

Fisheries production in Indonesia from 2011 to 2016 has increased, consisting of capture fisheries and aquaculture. Total aquaculture production is 17.22 million tons, while capture fisheries production is 6.04 million tons [1]. Prawn farming exports in Indonesia in 2015-2017 amounted to 393 thousand tons [2]. The increase in prawn production is due to several reasons, including pests and diseases that have been controlled, a huge market demand, and the absence of quotas set by the prawn importing countries so that the export opportunity is still huge. At present, the prawn commodities cultivated in Indonesia are vanamei prawn and tiger prawn. Tiger prawn (Penaeus monodon) is a leading export commodity in the fisheries sector. But in its development, the production of tiger prawns in Indonesia experiences various problems, one of which is the price of high protein feed is very expensive so that production costs also increase. The use of high protein can accelerate growth.

Prawn are arthropod animals that have a shell that performs growth by molting. [3] states that the molting stage changes physical criteria, deposition and collagen, carbohydrates, lipids, and calcium salts. Prawn need energy and hormones for the process of molting; the hormone needed is ecdysteroid. The raw material for ecdysteroid formation is cholesterol [4]. Improved feed quality must be met to meet the nutritional requirements for prawn growth. In addition to cholesterol, prawn growth also requires several other nutrients, lipids, protein, and carbohydrates. [5] A research reported that fats added were affected

\section{How to cite:}

Awaludin, Abdiani IM, Arsyidi, Rukisah (2020) Increasing Growth Tiger Prawn (Penaeus monodon) Using Organic Diet of Sauropus androgynous. Journal of Tropical Life Science 10 (3): 253 - 257. doi: 10.11594/jtls.10.03.09. 
the growth significantly. Prawn cannot produce cholesterol and lipids, so they are needed from a feed. One way to increase cholesterol, lipid, protein, and carbohydrate levels in feed is by using natural ingredients, such as $S$. androgynous leaves.

S. androgynous leaves a vegetable plant for breastfeeding mothers because $S$. androgynous plants contain estrogenic sterols, which have a role in increasing milk production [6]. Other research also mentioned that $S$. androgynous plants contain steroids [7]. S. androgynous leaves ethanol extract contains fatty acids and sterols $[8,9]$. Cholesterol is one of the chemicals that cannot be synthesized by crustaceans [10] but is highly needed for the maturation of ovarian brood stock and growth of tiger prawn [11]. Red spinach extract containing carbohydrates and fatty acids have the potential to shorten the duration of vannamei prawn molting by the soaking method. Cholesterol supplements for Litopenaeus vannamei maintained with a plant-based diet can promote growth [12]. S. androgynous contains sterol compounds derived from cholesterol, so this research needs to done to determine the use of organic diets from $S$. androgynous as feeding raw material for tiger prawn growth.

\section{Material and Methods}

\section{Sauropus androgynus leaves extraction}

Fresh leaves from $S$. androgynus plants were cleaned and dried at $24^{\circ} \mathrm{C}$ for about seven days. The dried plants were then powdered on size 60 mesh particle material. The powdered plants were extracted using the maceration method with $70 \%$ ethanol (Merck, $1: 3 \mathrm{w} / \mathrm{v}$ ). The simplicial were blended and soaked with ethanol for $3-4$ days. The extract was filtered using filter papers Whatman no.1, and the filtrate was concentrated by evaporated using a rotary evaporator $\left(60^{\circ} \mathrm{C}\right)$ to separate the extract from the solvent.

\section{Experimental}

This study used experimental research using completely randomized design 4 and 3 with the dosage of treatment 1 (control (T1)) without giving S. androgynous extract, treatment 2 (T2) 5 $\mathrm{g} / \mathrm{kg}$ of feed, treatment 3 (T3) $50 \mathrm{~g} / \mathrm{kg}$ of feed, and treatment 4 (T4) $100 \mathrm{~g} / \mathrm{kg}$ of feed [9]. Tiger prawns used are postlarva-14 with 50 stock/20 L stocking kept for 30 days. The feed is given in the form of artificial feed with a dose of $5 \%$ of body weight giving frequency three times a day, i.e. (morning, afternoon, and evening). Checking temperature and salinity is done in the morning and evening.

\section{Observation parameters \\ Proximate analysis}

Proximate analysis of $S$. androgynous extract in the science and technology laboratory of the animal husbandry faculty of IPB. 100-gram extract samples were then analyzed dry weight, ash content, crude protein, crude fiber, coarse fat, extract material without nitrogen.

\section{Biological analysis}

Diet performance was evaluated by using this formula [13]:

$$
\begin{gathered}
\text { Absolute weight growth }(\mathrm{g})= \\
\text { final weight }- \text { initial weight } \\
\text { Absolute length growth }(\mathrm{cm})= \\
\text { final length }- \text { initial length } \\
\text { Survival rate }(\%)= \\
\frac{\text { number of shrimps alive after treatment }}{\text { number alive in the beginning }} \times 100 \%
\end{gathered}
$$

\section{Results and Discussions}

\section{Proximate content of S. androgynous extract}

$S$. androgynous leaves used in this study were S. androgynous extract using ethanol. Proximate tests are performed to determine the nutritional content of the $S$. androgynous extract. The results of the proximate analysis test on $S$. androgynous extract can be seen in Table 1. Others research showed that $S$. andrygonus extract has ash content of $S$. androgynous leaf protein obtained (4.86.4), crude fat (1.0), crude fiber (1.5), ash content (1.7), and extract content without nitrogen (BETN) scored (26.56) [14, 15].

The primary sources of prawn feed nutrients are protein, carbohydrates, and fat. The protein content of the feed is a critical factor in supporting the success of prawn farming. Protein is a limiting factor for growth and dramatically influences the price of feed [16]. Based on the proximate test results, it suspected that $S$. androgynous extract can used as raw material for making an organic diet for the growth of tiger prawn. 


\section{Growth of tiger prawns by giving S. androgy- nous leaf extract to the feed}

The effect of the growth of tiger prawns by giving $S$. androgynous leaf ethanol extract, which was observed, consisted of weight gain and length gain. Growth of tiger prawn (P. monodon) using ethanol extract of $S$. androgynous leaves, with different concentrations during 30 days of maintenance, can be seen from Figure 1 .

The weight gain of tiger prawns by rearing using feed mixed with $S$. androgynous leaf extract was statistically significant $(\mathrm{P}<0.05)$. The highest weight growth was found in T4 by giving $S$. androgynous leaf extract with an average weight growth value $(70.18 \pm 9.57 \mathrm{~g})$. At the same time, the lowest weight growth was observed in T1 with an average weight growth value (32.62 $\pm 7.54 \mathrm{~g})$, T2 treatment of average weight growth (56.06 $\pm 8.89 \mathrm{~g})$ and average weight T3 (63, $58 \pm 13.88 \mathrm{~g}$ ). This is presumably because the addition of protein from S. androgynous leaf extract can increase the protein and nutrients of the feed given. Tiger prawn require nutritional elements for its growth. The items are protein, carbohydrates, fats, minerals, and vitamins. Optimal growth of tiger prawn requires protein-containing feed ranging from $35-40 \%$, fat $10-12 \%$, carbohydrate $40 \%$, cholesterol $0.5-1.0 \%$ and a few vitamins and minerals with the high nutritional content of feed will increase endurance prawn body so that survival rates are obtained and high crop productivity [17].

The previous study reported that $70 \%$ ethanol extract contained sterols [9]. Sterols are cholesterol precursors. Cholesterol is one of the chemicals that cannot be synthesized by crustaceans [10] but is needed for the maturation of ovarian brood stock and growth of tiger prawn. Increased rate of protein synthesis due to stimulation of the molting hormone causes apolysis (physical separation between the epidermis and endocuticles) [18]. So, it is suspected that giving $S$. androgynous extract containing sterols can increase protein synthesis by prawn so that it can increase growth. There are two stages in ecdysteroid biosynthesis, namely the conversion of cholesterol into 5 $\beta$-diketol and the conversion of $5 \beta$-diketol to a secreted product[19]. Ecdystoid hormones are hormones used in the molting process for the growth of crustaceans. The application to Crustacea animals in accelerating molting

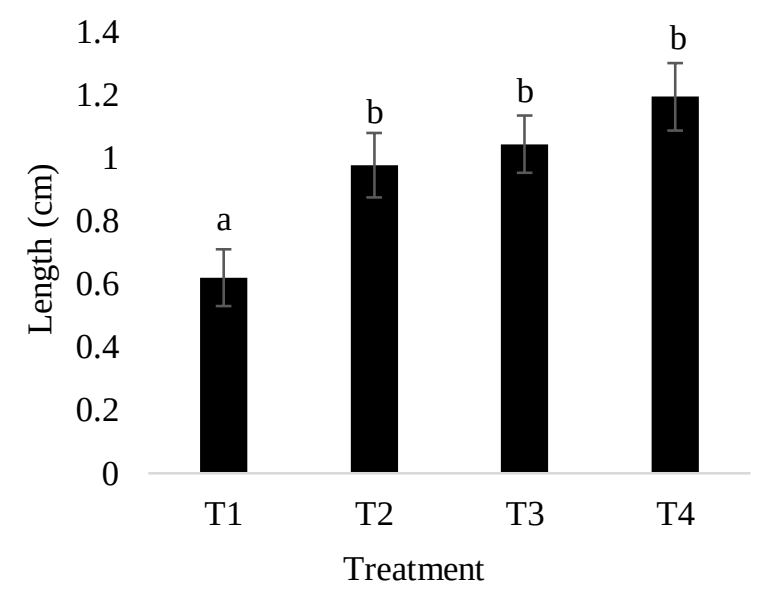

Figure 2. Average length of tiger prawns. T1 (Feed control without the addition of $S$. androgynous leaf extract); T2 (Addition of $S$. androgynous leaf extract $5 \mathrm{gr} / \mathrm{kg}$ of feed); T3 (addition of $S$. androgynous leaf extract 50 $\mathrm{gr} / \mathrm{kg}$ of feed); T4 (addition of $S$. androgynous leaf extract $100 \mathrm{gr} / \mathrm{kg}$ of feed). a and b: Significant 135 differences ( $p<0.05$ ) between means were determined using ANOVA.

like crabs is also widely practiced. The use of natural ingredients extracts from Nephrolepis biserrata containing steroids at a dose of 150 $\mathrm{mg} / \mathrm{L}$ can increase the frequency of molting [20, 21]. Another research reported that steroids in the form of ecdysteroid were able to influence the process of payment, trade and acceleration of crustacean [19].

The increase in the length of tiger prawns by rearing using feed mixed with $S$. androgynous leaf extract was statistically significant $(\mathrm{P}<0.05)$ (Figure 2). The highest length growth was found in T4 with average length $(1.19 \pm 0.10 \mathrm{~cm})$. In comparison, the lowest length growth was observed in $\mathrm{T} 1$ with average length growth $(0.62 \pm$ $0.09 \mathrm{~cm}$ ), whereas in growth T2 length with an average length $(0.97 \pm 0.10 \mathrm{~cm})$, and the average growth at T3 is $(1.04 \pm 0.09 \mathrm{~cm})$, giving $S$. androgynous leaves ethanol extract to the feed can increase body weight and be accompanied long growth in tiger prawn.

The survival of tiger prawns by giving S. androgynous leaf extract to the feed

Survival is a comparison of the number of individuals at the beginning of the maintenance 


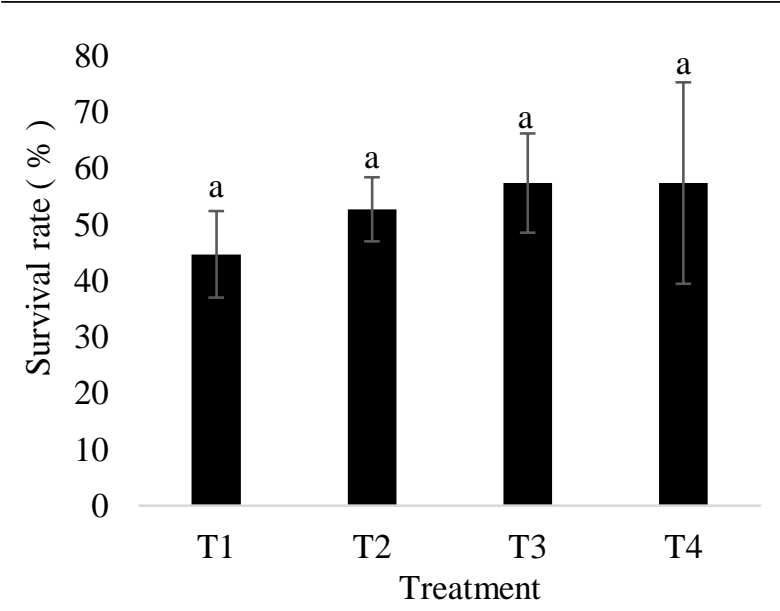

Figure 3. Average survival rate of tiger prawns. T1 (Feed control without the addition of $S$. androgynous leaf extract); T2 (Addition of $S$. androgynous leaf extract $5 \mathrm{gr} / \mathrm{kg}$ of feed); T3 (addition of $S$. androgynous leaf extract $50 \mathrm{gr} / \mathrm{kg}$ of feed); T4 (addition of S. androgynous leaf extract $100 \mathrm{gr} / \mathrm{kg}$ of feed).

period and the number of individuals living at the end of the period with the same population distribution. The survival rate states the percentage of tiger prawn that lived during the maintenance period. The survival rate of using $S$. androgynous leaf extracts mixed in feed for increased growth can be seen in Figure 3.

The survival rate of tiger prawns among treatments was not significantly different $(\mathrm{P}>$ $0.05)$. The survival of tiger prawn ( $P$. monodon) is cultivated, giving $S$. androgynous leaf extract to feed with a solid 50 individuals/20 L. In the control treatment, the survival rates were $\mathrm{T} 1$ (44.66\%), T2 (52.66\%), T3 (57.33\%), and T4 (57.33\%). The survival of tiger prawn is highest in T4 and lowest in T1. A study shows that $S$. androgynous plants that contain lanosterol could increase the survival rate of tiger prawns. The number of stable causes low survival value [22].

The ability of shrimps to consume dietary cholesterol and phytosterols such as ergosterol and isitosterol has been demonstrated [23]. Nutritional cholesterol is, therefore, considered essential for high crustacean growth and survival [24]. Cholesterol supplements for Litopenaeus vannamei maintained with a plant-based diet do not affect survival but affect growth [12]. S. androgynous extract dose used under a dosage of $552.208 \mathrm{mg} / \mathrm{L}$, which is a safe dose for tiger shrimp [9]. The high quality of the water media has been regulated conditions during the experi- ment. The water temperate ranged from 25.3$30^{\circ} \mathrm{C}$; the salinity ranges from 27-30; the $\mathrm{pH}$ ranges from 6.14-7.9; and the dissolved oxygen ranged from 5.28-8.43. At the time of the study, the water quality was the optimal condition for the growth of tiger prawns [13].

\section{Conclusion}

The giving S. androgynous leaf extract as organic diet to tiger prawn can improve the length and weight of tiger prawn. Giving $100 \mathrm{~g}$ extract of S. androgynous extract per kg feed can improve the weight of prawn until $70.18 \pm 9.57 \mathrm{gr}$ and length until $1.19 \pm 0.10 \mathrm{~cm}$.

\section{Acknowledgment}

This experiment was funded by the LPPM Universitas Borneo Tarakan through the sceme "Berbasis Visi Universitas Borneo Tarakan" Sumber Dana DIPA UBT 2020.

\section{References}

1. Kementerian Kelautan dan Perikanan (2018) Produktivitas Perikanan Indonesia. Kementerian Kelautan dan Perikanan, Jakarta.

2. Subdirectorate of Fishery Statistics (2018) Statistics of Fishery Establishment 2017. BPS-Statistics, Jakarta.

3. Promwikorn W, Boonyoung P, Kirirat P (2005) Histological characterization of cuticular depositions throughout the molting cycle of the black tiger shrimp. Songklanakarin Journal of Science and Technology 27 (3): 11.

4. Shrivastava S, Princy A (2013) Moult inhibiting hormone: a new approach to the discovery and design of growth promoters in crustaceans?. Reviews in Aquaculture 5 (2): 111-120. doi: 10.1111/raq.12007.

5. Sick LV, Andrews JW (2009) The Effect of Selected Dietary Lipids, Carbohydrates and Proteins on the Growth, Survival and Body Composition of Penaeus duorarum. Proc. Annu. Workshop - World Maric. Soc. 4 (1 - 4): 263-276. doi: 10.1111/j.17497345.1973.tb00111.x.

6. Prajonggo T, Djatmiko W, Soemarno T, Lunardi J (1983) Pengaruh Sauropus androgynus L. Mer terhadap gambaran histologi kelenjar susu mencit betina yang menyusui. Pros. Kongr. Nas. XI ISFI: 735-739.

7. Putranto HD, Ginting SM, Nurmeliasari, Yumiati Y (2014) Skrining Senyawa Metabolit Steroid sebagai Hormon Reproduksi Ternak pada Tanaman Katuk dan Jantung Pisang. Jurnal Peternakan Indonesia 16 (1): 20. doi: 10.25077/jpi.16.1.20-25.2014.

8. Subekti S (2007) Komponen Sterol Dalam Ekstrak Daun Katuk (Sauropus androgynus L. Mer) dan Hubungannya dengan Sistem Reproduksi Puyuh. Doctoral Thesis. Ins- 
titut Pertanian Bogor.

9. Awaludin A, Kartina K, Maulianawati D et al. (2020) Phytochemical screening and toxicity of ethanol extract of Sauropus androgynus. Biodiversitas Journal of Biological Diversity 21 (7): 2966-2970. doi: 10.13057/biodiv/d210712.

10. Kanazawa A, Chim L, Laubier A (1988) Tissue uptake of radioactive cholesterol in the prawn Penaeus japonicus Bate during induced ovarian maturation. Aquatic Living Resources 1 (2): 85-91. doi: 10.1051/alr:1988010.

11. Lisnawati L, Ridwan A (2019) Potensi Ekstrak Bayam Merah (Amaranthus tricolor) Dalam Mempersingkat Durasi Molting Udang Vannamei (Litopenaeus vannamei) Dengan metode Dipping. Bachelor Thesis. Institut Teknologi Bandung.

12. Morris TC, Samocha TM, Davis DA, Fox JM (2011) Cholesterol supplements for Litopenaeus vannamei reared on plant-based diets in the presence of natural productivity. Aquaculture 314 (1-4): 140-144. doi: 10.1016/j.aquaculture.2011.01.052.

13. Bautista-Teruel MN, Eusebio PS, Welsh TP (2003) Utilization of feed pea, Pisum sativum, meal as a protein source in practical diets for juvenile tiger shrimp, Penaeus monodon. Aquaculture 225 (1-4): 121-131. doi: 10.1016/S0044-8486(03)00284-9.

14. Wiradimadja R (2007) Dinamika Status Kolesterol Pada Puyuh Jepang (Coturnix coturnix japonica) yang Diberi Daun Katuk (Sauropus androgynus L Merr.) Dalam Ransum. Doctoral Thesis. Institut Pertanian Bogor.

15. Rais R, Yustendi D (2019) Pengaruh Pemberian Ekstrak Daun Katuk (Sauropus androgynus L.Merr) Dalam Air Minum Kambing Perah Peranakan Ettawa Terhadap Konsumsi Pakan. Prosiding SEMDI-UNAYA (Seminar Nasional Multi Disiplin Ilmu UNAYA) 3 (1): 6.

16. Kureshy N, Davis DA (2002) Protein requirement for maintenance and maximum weight gain for the Pacific white shrimp, Litopenaeus vannamei. Aquaculture 204
$(1-2)$ : 125 - 143. doi: 10.1016/S0044-8486(01)006494.

17. Pujianti P, Rachmawati D (2014) Performa Kematangan Gonad, Fekunditas, dan Derajat Penetasan Udang Windu (Penaeus monodon Fab.) melalui Subtitusi Cacing Laut dengan Cacing Tanah. Journal of Aquaculture Management and Technology 3 (8): 158 - 165.

18. Fujaya Y, Aslamyah S, Usman Z (2011) Respon Molting, Pertumbuhan, dan Mortalitas Kepiting Bakau (Scylla olivacea) yang Disuplementasi Vitomolt melalui Injeksi dan Pakan Buatan. ILMU KELAUTAN: Indonesian Journal of Marine Sciences 16 (8): 211 - 218. doi: 10.14710/ik.ijms.16.4.211-218.

19. Mykles DL (2011) Ecdysteroid metabolism in crustaceans. The Journal of Steroid Biochemistry and Molecular Biology 127 (3-5): 196-203. doi: 10.1016/j.jsbmb.2010.09.001.

20. Maulianawati D, Awaludin A (2018) Uji Toksisitas dan Analisis Kandungan Fitokimia Ekstrak Methanol dan Kloroform Daun Paku Uban (Nephlorepis bisserata). Jurnal Harpodon Borneo 68-74: 7.

21. Maulianawati D, Rukisah R, Awaludin A, Guntur MI (2020) Utilization of Paku Uban (Nephrolepis biserrata) Extract as a Molting Stimulant of Mud Crabs (Scylla spp.) in Traditional Ponds. Jurnal Ilmiah Perikanan dan Kelautan 12 (1): 113. doi: 10.20473/jipk.v12i1.14053.

22. Awaludin A, Ridwan A (2016) Peningkatan Survival rate Benih Udang Windu (Peaneus monodon) dengan Perendaman Ekstrak Etanol Karamunting (Melastoma malabahricum). Jurnal Harpodon Borneo 9: 32-35.

23. Teshima S, Kanazawa A, Okamoto H (1974) Absorption of sterols and cholesteryl esters in a prawn, Penaeus japonicus. Nippon Suisan Gakkaishi 40 (10): 1015 - 1019. doi: 10.2331/suisan.40.1015.

24. Sheen SS, Liu PC, Chen SN, Chen JC (1994) Cholesterol requirement of juvenile tiger shrimp (Penaeus monodon). Aquaculture 125 (1-2): 131-137. doi: 10.1016/0044-8486(94)90289-5. 
This page is intentionally left blank 